\title{
EVALUATING SERUM C-REACTIVE PROTEIN LEVEL IN PATIENTS WITH CHRONIC OBSTRUCTIVE PULMONARY DISEASE - A CROSS-SECTIONAL STUDY
}

\author{
${ }^{1}$ Dr. Karthika. M, ${ }^{2}$ Dr. Prakash Chandra Bhardwaj, ${ }^{3}$ Dr.Laimayum Amarnath Sharma, ${ }^{4}$ Dr. W Kanan, ${ }^{5}$ Dr. W Asoka Singh \\ ${ }^{I}$ SeniorResident, Department of Physiology, JIPMER, Puducherry, India. \\ ${ }^{2} M D$ (Physiology), Department of Health Services, Manipur, India. \\ ${ }^{3}$ Medical Officer, DR TB Center, JNIMS Hospital, Imphal, Manipur, India. \\ ${ }^{4}$ Professor \& Head Department of Physiology, Regional Institute of Medical Sciences, Imphal, Manipur, India. \\ ${ }^{5}$ Professor Department of Respiratory Medicine, Regional Institute of Medical Sciences, Imphal, Manipur, India.
}

\section{Alostract}

Patients with the chronic obstructive pulmonary disease have an ongoing systemic inflammation, which can be assessed by measuring serum C- reactive protein. Objective: To explore whether CRP could be used as an independent predictor of disease outcome in COPD. Methods: A cross-sectional study was conducted among 50 COPD patients attending Respiratory Medicine outpatient services in Regional Institute of Medical Sciences (RIMS), Imphal from January 2015 to September 2016. Patients aged 18-67 were included in the study after obtaining Ethical approval from the Research Ethics Board, RIMS, Imphal. Computerized Spirometer Helios 401 was the instrument used to measure lung volumes and capacities. BeneSphera ${ }^{\mathrm{TM}}$ CRP Latex Slide test kit was used to estimate serum c-reactive protein. Results: The present study was conducted on fifty COPD patients in which serum CRP level showed positive correlation with COPD $(\mathrm{p}=0.002)$ but serum CRP level with spirometric parameters showed significant negative correlation; $\mathrm{FEV}_{1}(\mathrm{r}=-0.451, \mathrm{p}=0.001), \mathrm{FEV}_{1} / \mathrm{FVC}(\mathrm{r}=-0.617, \mathrm{p}<0.001)$ and $\mathrm{PEFR}(\mathrm{r}=-$ 0.398, $\mathrm{p}=0.004)$. Conclusion: In our study we found an association between serum CRP level and severity of COPD and Plasma CRP may be used as a marker of prognosis in COPD as small increase is associated with poorer prognosis in COPD.

Keywords: CRP; Chronic obstructive pulmonary disease (COPD); Imphal.

\section{Introduction}

Obstructive airways disease is a group of condition distinguished by increased resistance and obstruction in the air passages, especially during expiration. The term OAD includes bronchial asthma; chronic obstructive pulmonary disease, consisting of chronic bronchitis and emphysema; bronchiectasis; cystic fibrosis and bronchiolitis [1].

COPD is a disease state characterized by airflow limitation that is not fully reversible. The airflow obstruction is usually both progressive and associated with an abnormal inflammatory response of the lungs to noxious particles and gas. There are around 50 million patients with COPD in India and COPD is the second leading cause of death in India. An estimate suggests that COPD will rise from the sixth to the third most common cause of death worldwide by 2020 [2].

Diagnosis of OAD is based on the patient's history, signs, and symptoms, and on the results of spirometry and other pulmonary function tests. Spirometry assesses the obstruction of expiratory airflow, which is the characteristic functional defect in OAD. Spirometry is the most effective way of determining the severity of obstructive airway diseases [3].

C-reactive protein was first isolated in 1930 from the plasma of patients with pneumococcal pneumonia, CRP was so

eISSN: 2523-6709

pISSN: 2523-6695

DOI: $10.31878 /$ ijcrpp.2019.34.1 named because it binds to the C-polysaccharide of the pneumococcus. Modern molecular studies have determined that CRP is a member of the pentraxin family of proteins. It comprises five protomers, each of 206 amino acids, molecular weight $23 \mathrm{kDa}$, arranged in cyclic symmetry. With the participation of $\mathrm{Ca}^{2}$ ions, it binds various proteins and phospholipids, particularly phosphocholine. It opsonizes particles and also activates complement via the classical pathway, but its actual biological function is unknown [4].

In the lungs, CRP has a protective function by acting against bacteria and apoptotic cells. Activated epithelial cells, alveolar macrophages and other inflammatory cells in COPD release IL-6 into the circulation. CRP is primarily produced by hepatocytes in response to IL-6 stimulation [5]. This stimulates an acute-phase response and increases the level of plasma CRP. C-reactive protein appears in blood in the acute stages of various inflammatory disorders but is undetectable in the blood of healthy persons [6].

Worldwide studies show that it has variable roles in COPD, some showing correlation with spirometric lung function while others show no significant relation. We would, therefore, like to explore its role in our study population and also try to explore whether it could become an independent predictor of disease outcome in COPD.

\section{Materials and Methods}

Study design: A cross-sectional study was conducted among 50 COPD patients attending Respiratory Medicine outpatient services in Regional Institute of Medical Sciences (RIMS), Imphal from January 2015 to September 2016. Patients aged 18-67 were included in the study after obtaining Ethical

Correspondence: Dr. Karthika. M, Senior Resident, Department of Physiology, JIPMER, Puducherry, India E-Mail: mkarthikambbs@gmail.com 
approval from the Research Ethics Board, RIMS, Imphal. The participants were recruited by Purposive sampling. Diagnosed COPD patients sent from Respiratory Medicine OPD, RIMS, Imphal were included in this study.

The patients with chronic disorders like hypertension, diabetes mellitus, cardiovascular diseases, bleeding disorders, inflammatory disorders, infection, malignancy and patients who had recent surgery were excluded from the study.

Computerized Spirometer Helios 401 of the Recorders and Medicare System, Chandigarh, India was the instrument used to measure lung volumes and capacities. The Helios software contains a set of prediction equations for computation of predicted parameter values.

The procedure was explained to the patient followed by a demonstration. The patient was asked to "take as deep a breath as possible" and then "blast as fast and hard as you can" and "keep blowing until I ask you to stop" preferably at least 3 seconds followed by a rapid inhalation (inspiration). A tight seal was ensured around the mouthpiece. During the test, a soft nose clip was used to prevent air from escaping through the nose. Coaching was active and vigorous; instructions were repeated as necessary. Three consecutive maneuvers were performed with a rest of 5 to 10 minutes between two maneuvers.

The best result among the three tests was recorded in the proforma. The results were compared with the predicted values for the same age, sex, height, and weight. Patients were classified on the basis of the GOLD Classification of COPD (2006) [7].

The study variables which include Forced Vital Capacity (FVC), Forced Expiratory Volume in one second $\left(\mathrm{FEV}_{1}\right)$, $\mathrm{FEV}_{1} / \mathrm{FVC}$ ratio, Forced Expiratory Flow during $25-75 \%$ of expiratory flow (FEF $25-75 \%$ ), and Peak Expiratory Flow Rate (PEFR), were recorded by Helios Computerized Spirometer Model No. 401, in a sitting position. Spirometric values are better when done in a standing position but sitting posture is usually preferred because of the risk of fall due to cough syncope when done in standing.
BeneSphera $^{\mathrm{TM}}$ CRP Latex Slide test kit of Avantor Performance Materials India Ltd, Dehradun, Uttarakhand, was used to estimate serum c-reactive protein in human. The test was expected to be positive with serum CRP levels between 0.6 and $100 \mathrm{mg} / \mathrm{dl}$.

\section{Statistical analysis}

The collected data were entered and analyzed using IBM SPSS Statistics V21.0 (IBM Corporation, US). Summarizations of data for frequency distribution for variables of interest were carried out by using descriptive statistics such as mean, standard deviation and percentages. Chi-square test was employed to test the association between asthma with variables of interest. A p-value of $<0.05$ was considered to be statistically significant.

\section{Results}

A total of 50 patients with the chronic obstructive pulmonary disease were included in the study. Of which Maximum percentage $(92 \%)$ of patients belong to the age group (38-67 years ) while minimum percentage $(8 \%)$ of the patients belong to age group (18-37 years). About two-thirds of the Obstructive Airway Disease patients were male. Out of 50, $32 \%$ patients were non-smoker, $38 \%$ were smoker, and $30 \%$ were ex-smokers and smoking pack years was less than 100 in $38 \%$ and more than 100 in $62 \%$ in the study population.

Socio-demographic characteristics like age, sex, smoking history were recorded. Thorough physical examination, degree of airflow obstruction and serum C-reactive protein were recorded after obtaining Prior written informed consent form from all the participants. Patients were classified on the basis of the GOLD Classification of COPD.

We found that $22 \%$ of COPD patients were in moderate category $\left(\mathrm{FEV}_{1} / \mathrm{FVC}<0.70\right.$ and $\left.\mathrm{FEV}_{1}=0.50-0.80\right), 18 \%$ of patients were in severe category $\left(\mathrm{FEV}_{1} / \mathrm{FVC}<0.70\right.$, and $\left.\mathrm{FEV}_{1}=0.30-0.50\right)$, and $14 \%$ of patients were classified as very severe $\left(\mathrm{FEV}_{1} / \mathrm{FVC}<0.70\right.$, and $\left.\mathrm{FEV}_{1}<0.30\right)$. Only $6 \%$ of the patients had mild airflow limitation while $40 \%$ of COPD patients had no airflow limitation during spirometry.

Table 1. Mean \pm SD of FVC, FEV, FEV $_{1} / F_{\text {FC, }}$ FEF $_{25-75 \%}$, and PEFR in COPD patients (n=50)

\begin{tabular}{ccccc}
\hline $\begin{array}{c}\text { Spirometric } \\
\text { parameters }\end{array}$ & $\begin{array}{c}\text { Minimum Value } \\
(\% \text { pred) }\end{array}$ & $\begin{array}{c}\text { Maximum Value } \\
(\% \text { pred) }\end{array}$ & $\begin{array}{c}\text { Mean } \\
(\% \text { pred) }\end{array}$ & Standard Deviation \\
\hline $\mathrm{FVC}$ & 36.00 & 158.00 & 83.96 & 30.98 \\
$\mathrm{FEV}_{1}$ & 9.00 & 155.00 & 61.16 & 32.63 \\
$\mathrm{FEV}_{1} / \mathrm{FVC}$ & 11.00 & 111.00 & 71.06 & 20.25 \\
$\mathrm{FEF}_{25-75 \%}$ & 6.00 & 138.00 & 34.20 & 27.53 \\
$\mathrm{PEFR}$ & 6.00 & 87.00 & 34.70 & 19.70 \\
\hline
\end{tabular}

Table 2. Association of the serum CRP level with the severity of COPD

\begin{tabular}{|c|c|c|c|c|c|}
\hline \multirow{2}{*}{$\begin{array}{c}\text { Severity of } \\
\text { COPD }\end{array}$} & \multicolumn{3}{|c|}{ CRP } & \multirow{2}{*}{ Total } & \multirow{2}{*}{ p-value* } \\
\cline { 2 - 5 } & $\begin{array}{c}\text { LESS THAN } \\
6 \mathrm{mg} / \mathrm{L}\end{array}$ & $6 \mathrm{mg} / \mathrm{L}$ & $12 \mathrm{mg} / \mathrm{L}$ & \\
\hline Normal & 19 & 1 & 0 & 20 & \\
Mild & 1 & 2 & 0 & 3 & 0.002 \\
Moderate & 5 & 3 & 2 & 9 & 7 \\
Severe & 4 & 3 & 4 & 50 & \\
Very severe & 1 & 2 & 9 & \\
Total & 30 & 11 & & \\
\hline
\end{tabular}

*Chi-Square Test 
Table 1 shows the lung function test values of COPD patients as measured by a spirometer. FVC values were within normal limit. But the mean values of $\mathrm{FEV}_{1}, \mathrm{FEF}_{25-75 \% \text {, and PEFR }}$ were lower. The results suggest that in the COPD patients larger and smaller airways both were involved.

Above table shows the association between serum CRP level and severity of COPD. Total $9(18 \%)$ COPD patients had serum CRP level $12 \mathrm{mg} / \mathrm{L}$, in which $3(6 \%)$ patients belong to moderate category, $2(4 \%)$ patients belong to severe category, and $4(8 \%)$ patients belong to very severe category. And 11 $(22 \%)$ COPD patients had serum CRP level $6 \mathrm{mg} / \mathrm{L}$, it included; $1(2 \%)$ patient with normal spirometry, $2(4 \%)$ patients were in mild category, 3(6\%) patients were in each moderate and severe category, and $2(4 \%)$ patients were in very severe category $(\mathrm{p}=0.002)$.

Table 3. Correlation of different parameters of spirometry and age with serum CRP level in COPD patients $(\mathbf{n}=\mathbf{5 0})$

\begin{tabular}{ccc}
\hline Variables & $\begin{array}{c}\text { Correlation coeffi- } \\
\text { cient (r)* }\end{array}$ & p-value \\
\hline $\mathrm{FEV}_{1}$ & -0.451 & 0.001 \\
$\mathrm{FEV}_{1} / \mathrm{FVC}$ & -0.617 & $<0.001$ \\
$\mathrm{PEFR}$ & -0.398 & 0.004 \\
\hline
\end{tabular}

*Pearson`s bivariate correlation coefficient

Table 3 shows that age, $\mathrm{FEV}_{1}, \mathrm{FEV}_{1} / \mathrm{FVC}$, and PEFR were negatively correlated with serum $\mathrm{C}$-reactive protein.

\section{Discussion}

COPD is the second leading cause of death in India and the disability from this disease is substantial and is expected to rise in India and worldwide. There are evidences pointing towards smoking being a risk factor COPD and for increased clinical symptoms and poorer lung function in COPD patients. Hence all possible efforts should be taken to make people quit smoking, by adopting more awareness and control programs. But smoking cessation is challenging so education advice, behavioral intervention along with drug therapy like nicotine replacement therapy with gums, patch or inhaler can be tried for better results.

The treatments available today have a minimum impact on the disease progression, so early diagnosis and treatment are necessary. Measures such as screening with spirometric tests in high-risk individuals especially the smokers in age group of 40-55 should be considered to reduce the mortality and morbidity due to COPD. In this study we were trying to find whether CRP levels can be used as a valid tool and an independent predictor of disease outcome in COPD so that it could be used to evaluate the clinical, prognostic and therapeutic outcomes.

The present study was conducted on fifty COPD patients in which serum CRP level showed positive correlation with COPD $(p=0.002)$ but serum CRP level with spirometric parameters showed significant negative correlation; $\mathrm{FEV}_{1}(\mathrm{r}=-$ $0.451, \mathrm{p}=0.001), \mathrm{FEV}_{1} / \mathrm{FVC}(\mathrm{r}=-0.617, \mathrm{p}=0.000)$ and PEFR $(\mathrm{r}=-0.398, \mathrm{p}=0.004)$.
There are evidences supporting our study from previous research work conducted by Moreton RE and Kennedy CR reported that CRP concentration in patients (age range 0.0316.1 years, median: 6.7 years) with cystic fibrosis ranged from $0.01-304 \mathrm{mg} / \mathrm{L}$ while in healthy children ranged from $0.01-2.8 \mathrm{mg} / \mathrm{L}$ and correlation between $\mathrm{CRP}$ and $\mathrm{FVC} \%$ predicted was significant $(\mathrm{r}=-0.781 ; \mathrm{p}<001)$ [8].

Gan and colleagues aggregated data from five cross-sectional studies and estimated an average mean increase in serum CRP of $1.85 \mathrm{mg} / \mathrm{L}$ in individuals with stable COPD [9]. There were similar results in the study conducted by Fares $M$ et al [10]. They showed that CRP level $>1.1 \mathrm{mg} / \mathrm{L}$ in infants with bronchiolitis. Hsieh $\mathrm{MH}$ et al [11] found a good correlation between serum hs-CRP and HRCT scores in the patients with stable non-cystic fibrosis bronchiectasis.

Similar results were shown in the study conducted by Tores et al [12] and Seemungal et al [13] the mean CRP level between the control group and COPD group were compared and was different by greater than $3.3 \mathrm{mg} / \mathrm{L}$, which was found to be significant $(\mathrm{P}<0.001)$.

\section{Conclusion}

In this study, we were trying to find whether CRP proteins levels can be used as a valid tool in COPD patients so that it could be used to evaluate the clinical, prognostic and therapeutic outcomes. In our study we found association between serum CRP level and severity of COPD and Plasma CRP may be used as a marker of prognosis in COPD as small increase is associated with poorer prognosis in COPD.

\section{Limitations}

The serum CRP has been used for evaluation of COPD and other inflammatory conditions but several factors might affect serum levels of CRP. CRP may be elevated in obese individuals and also in people who have the habit of smoking. Ageing is also another confounding factor. Further longitudinal studies are necessary to evaluate whether CRP could be used as an independent predictor of disease outcome.

Ethical clearance: Ethical approval was obtained from the Research Ethics Board, RIMS, Imphal before the beginning of the study.

\section{Source of funding: Self}

\section{Conflict of Interest: Nil}

\section{Acknowledgment}

We acknowledge great help received from the scholars whose articles are cited and included in the references of this manuscript.

\section{References}

[1] Weinberger SE, Rosen IM. Disturbances of respiratory function. In: Loscalzo J, editor. Harrison`s Pulmonary and Critical Care Medicine. New Delhi: McGraw-Hill; 2010. [Google Scholar]

[2] Mannino DM, Buist AS. Global burden of COPD: risk factors, prevalence, and future trends. Lancet 2007;370 (9589):765-73. [Google Scholar]

[3] Bellamy D. Spirometry in practice: A practical guide to using spirometry in primary care. 2nd ed. London: BTS 
COPD Consortium; 2005. [Google Scholar]

[4] Block JL. Evaluation of cardiac injury and function. In: McPherson RA, Pincus MR, editors. Henry`s Clinical Diagnosis and Management by Laboratory Methods. 21st ed. New Delhi: Elsevier; 2009. [Google Scholar]

[5] Yoshida M, Sakuma J, Hayashi S, Abe K, Saito I, Harada S, et al. A histologically distinctive interstitial pneumonia induced by overexpression of the interleukin 6 , transforming growth factor $\beta 1$, or platelet-derived growth factor B gene. Proc Natl Acad Sci USA 1995;92:9570. [Google Scholar]

[6] Sonnenwirth AC. Serological tests in infectious diseaseII. In: Sonnenwirth, Jarett L, editors. Gradwohl's Clinical Laboratory Methods and Diagonosis. 8th ed. New Delhi: B.I. Publications Ltd; 1990. [Google Scholar]

[7] Global strategy for the diagnosis, management, and prevention of chronic obstructive pulmonary disease (2006). Available at: http://www.goldcopd.org. Accessed September 19, 2016.

[8] Moreton RE, Kennedy CR. C reactive protein concentrations in cystic fibrosis. Arch Dis Child 1988;63:958-60. [Google Scholar]
[9] Gan WQ, Man SFP, Senthilselvan A, Sin DD. Association between chronic obstructive pulmonary disease and systemic inflammation: a systematic review and a meta-analysis. Thorax 2004;59:574. [Google Scholarl

[10] Fares M, Mourad S, Rajab M, Rifai N. The use of Creactive protein in predicting bacterial co-infection in children with bronchiolitis. N Am J MedSci 2011;3 (3):152-6. [Google Scholar]

[11] Hsieh MH, Fang YF, Chen GY, Chung FT, Liu YC, $\mathrm{Wu} \mathrm{CH}$, et al. The role of the high-sensitivity $\mathrm{C}$-reactive protein in patients with stable non-cystic fibrosis bronchiectasis. Pulm Med 2013;2013(1):1-8. [Google Scholarl

[12] Torres J. P. de, Cordoba-Lanus E., López-Aguilar C., Fuentes M. Muros de, Garcini A. Montejo de, AguirreJaime A. C-reactive protein levels and clinically important predictive outcomes in stable COPD patients. The European Respiratory Journal 2006;27:9027. [Google Scholar]

[13] Seemungal T. A., Lun J. C., Davis G., Neblett C., Chinyepi N., Dookhan C.. Plasma homocysteine is elevated in COPD patients and is related to COPD severity. International Journal of Chronic Obstructive Pulmonary Disease 2007;2:313-21. [Google Scholar] 